\title{
IISGS
Snake Fungal Disease in North America: U.S. Geological Survey Updates
}

\author{
By Noelle E. Thompson', Emily W. Lankau², and Gail Moede Rogall
}

Snake fungal disease (SFD) results from a skin infection that has been documented only in snakes. Historically, reports of snakes with skin infections of unknown origin have been sporadic. Recently, the number of reported cases of skin infections in snakes has increased substantially. This emerging infectious disease, confirmed in numerous species of snakes, is caused by the fungus Ophidiomyces ophiodiicola. As of August 2017, O. ophiodiicola has been detected in at least 23 States and one Canadian Province. However, researchers suspect that SFD may be more widely distributed than these documented cases suggest because efforts to monitor the health of many snake populations are limited. Snake fungal disease may also be underreported in populations where it affects snakes infrequently or in species that develop less severe illness. Signs of SFD include crusted or ulcerated scales, nodules (that is, abnormal bumps) under the skin, and facial disfiguration that can be quite severe, leading to emaciation and death. Many snake populations are already in decline due to habitat loss and dwindling prey populations, and the recent emergence of SFD may accelerate this decline, causing certain species to disappear entirely from some locations (Allender and others, 2015; Lorch and others, 2016).

Snakes play a vital role in natural food webs as both prey and predator. Besides being an important food item for many mammal and bird species (Mullin and Siegel, 2009), snakes consume a variety of prey, including rodents that can damage agricultural crops or carry diseases that affect people and other animals. For example, snakes can reduce local incidence of Lyme disease by consuming rodents and other small mammals infested with ticks that transmit Lyme disease. Mathematical models suggest that a single Crotalus horridus (timber rattlesnake) reduces the number of ticks within its foraging range by 2,500-4,500 annually; other viper species likely provide similar disease-control services (Kabay and others, 2013).

Figure 1. Sistrurus catenatus (eastern massasauga rattlesnake) populations in the Midwestern United States have been heavily affected by habitat destruction and fragmentation (U.S. Fish and Wildlife Service, 2016) and recently, snake fungal disease. Photo by Rori Paloski, Wisconsin Department of Natural Resources.

${ }^{1}$ University of Illinois at Urbana-Champaign.

${ }^{2}$ U.S. Geological Survey.
Field biologists have sporadically detected skin lesions (that is, sores) in wild North American snakes for decades, most often after snakes emerge from hibernation (Lorch and others, 2016). These lesions were colloquially called "hibernation sores," but the specific cause of these lesions was unknown until an investigation of deadly outbreaks of skin lesions in Sistrusrus catenatus (eastern massasauga rattlesnakes) in 2008 implicated a fungal pathogen (Allender and others, 2011). The fungus, O. ophiodiicola (formerly Chrysosporium ophiodiicola), was later also isolated from a skin nodule in a captive Pantherophis alleghaniensis (eastern rat snake; previously classified as Elaphe obsoleta obsoleta) (Rajeev and others, 2009). Ophidiomyces ophiodiicola was also found later during a study of archived tissue samples commonly associated with skin lesions in captive snakes (Sigler and others, 2013). After 2008, increasing numbers of snakes with fungal skin infections were reported, including additional cases in imperiled populations of eastern massasauga rattlesnakes in central Illinois and timber rattlesnakes in New England (Allender and others, 2015; McBride and others, 2015; fig. 1). These new reports caused increased concern about SFD and the potential for substantial declines in some snake populations, exacerbating risk for local extinction of both eastern massasauga rattlesnakes in central Illinois and timber rattlesnakes in New England (Allender and others, 2011, 2015).

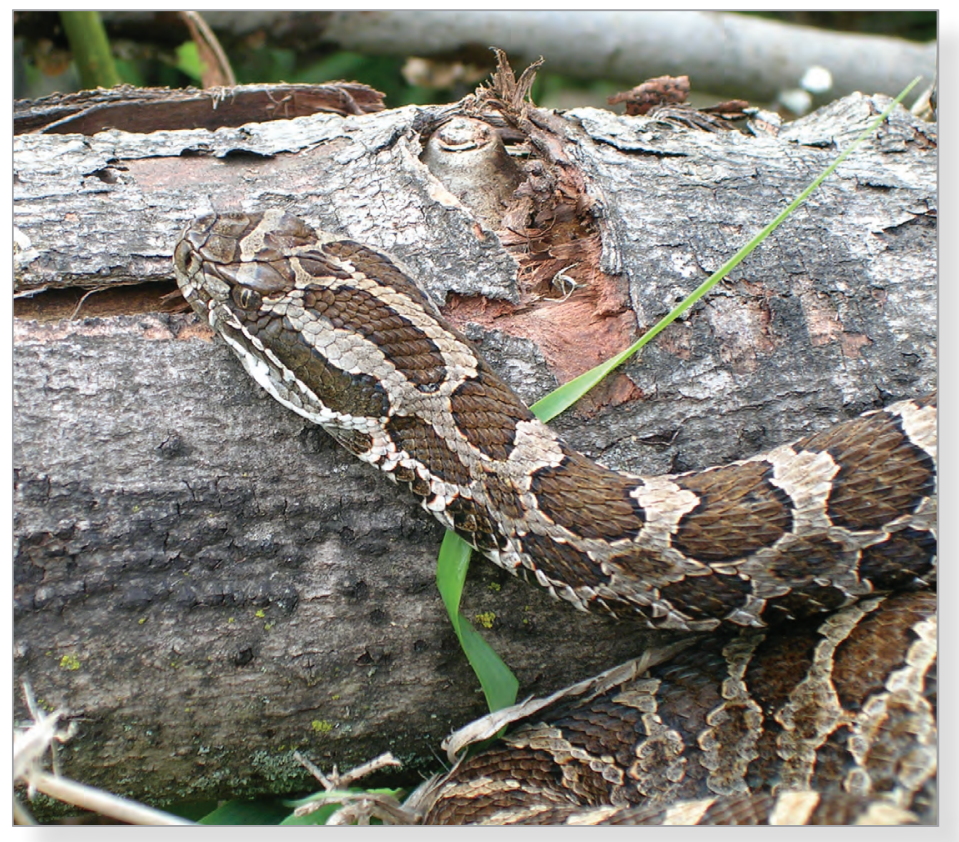


U.S. Geological Survey (USGS) scientists at the National Wildlife Health Center (https://www.nwhc.usgs.gov/) and the Wetland Aquatic Research Center (https://www.usgs.gov/warc) have worked closely with government, nonprofit, and academic partners to understand SFD and develop strategies to mitigate its effects on snake populations. Together, these scientists have advanced basic understanding of the cause, number of cases, and geographic distribution of SFD in several ways, including associating physical signs of fungal infection with a diagnosis (Sigler and others, 2013; Allender and others 2015; Lorch and others, 2016); experimentally demonstrating that the fungus $O$. ophiodiicola is the cause of SFD (Allender and others, 2015; Lorch and others, 2016); and establishing surveillance and monitoring systems to determine which snake species are infected by SFD in different regions (Lorch and others, 2016).

Physical signs and severity of SFD appear to vary among snake species and individuals, although factors contributing to this variability are poorly understood (Lorch and others, 2016). Visible signs of SFD may include scabs, skin ulcers or nodules, crusted scales, discolored scales, cloudy eyes, and a swollen or disfigured face (fig. 2). Snakes with SFD experience abnormal molting, and the upper layer of infected skin may be shed repeatedly in an effort to eliminate the fungus (Lorch and others, 2015). Affected snakes are often emaciated, possibly due to decreased ability to capture prey (Lorch and others, 2016). Additionally, they often rest in open, unprotected areas, exposing themselves to adverse weather and predators (Lorch and others 2015; McBride and others, 2015).

Ophidiomyces ophiodiicola can survive in a relatively wide range of $\mathrm{pH}$ and temperature conditions; however, growth of this fungus is inhibited by high air temperatures of more than 100 degrees Fahrenheit and moderately cold temperatures of less than 50 degrees Fahrenheit (Rajeev and others, 2009; Sigler and others, 2013; Allender and others, 2015). Ophidiomyces ophiodiicola can be transmitted by snake-to-snake contact and may persist in the environment without a snake host (Allender and others, 2015). Broken skin facilitates infection of snakes, but skin abrasions are not necessary for a snake to become infected (Lorch and others, 2015). Snakes can also carry O. ophiodiicola on their skin without exhibiting signs of infection (Paré and others, 2013; Bohuski and others, 2015). Thus, detection of the fungus alone is insufficient evidence to document that a snake has SFD.

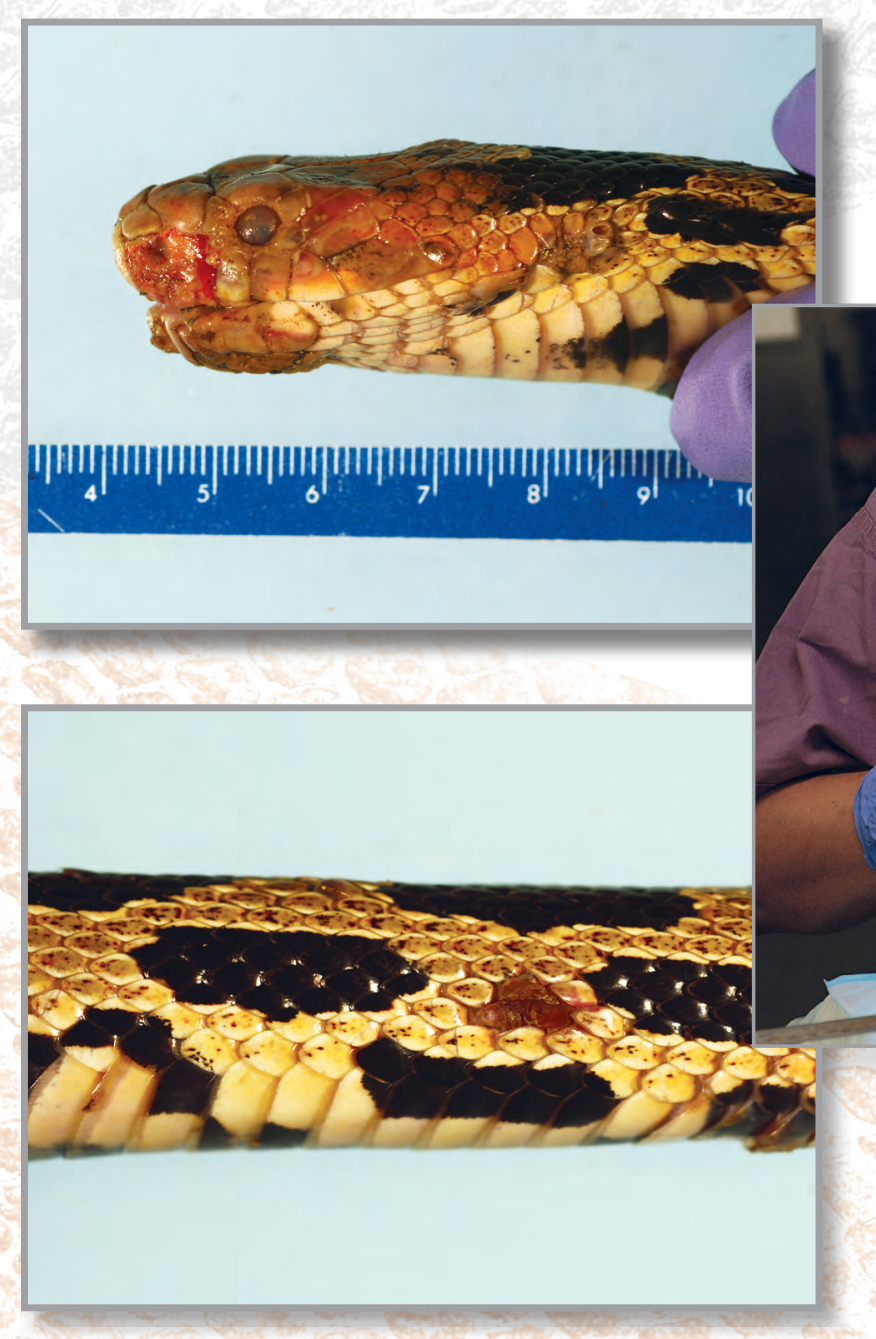

Figure 2. An Elaphe vulpine (western foxsnake) captured in Wisconsin presenting signs of snake fungal disease including $A$ (top left), skin ulcers on the nose and near the eyes and $B$ (bottom left), discolored, crusted scales on the body. Photos by Stephanie Steinfeldt, U.S. Geological Survey.

Figure 3 (above). National Wildlife Health Center pathologist Susan Knowles obtains a skin biopsy for analysis under a microscope from a Coluber constrictor (North American racer) submitted for diagnostic testing. Photo by Jennifer Swan, U.S. Geological Survey. 
Although $O$. ophiodiicola can be detected using laboratory techniques, microscopic examination of a biopsy, a piece of skin and underlying tissues, is required to confirm a diagnosis of SFD (fig. 3) through identification of inflammation and other signs of the invasive fungal infection. This serves to differentiate mere presence of the fungus on the skin of an otherwise-healthy animal from a skin infection characteristic of SFD.

It is unclear when or why $O$. ophiodiicola emerged as a fungal pathogen that harms snakes. Ophidiomyces ophiodiicola has been found throughout the eastern United States and may be native to this region. However, severe outbreaks of SFD have been documented in only a few locations throughout the country. Scientists hypothesize that environmental and climatic changes such as habitat destruction and fragmentation, increasing average temperatures, and cooler, wetter springs may be contributing to the recent emergence of this disease (Lorch and others, 2016). Concern about SFD has resulted in enhanced monitoring of snake populations across the United States, which could also contribute to documenting apparent trends of increasing frequency or severity of SFD as a result of increased awareness and surveillance.
The public can help with monitoring and response to SFD by reporting sightings of snakes with skin sores or abnormal behavior to a local or state wildlife agency. However, members of the general public should avoid disturbing wild snakes.

To avoid inadvertent spread of pathogens, researchers and other wildlife professionals should observe universal precautions by thoroughly cleaning and sanitizing clothing and equipment that has been in contact with wild snakes, and by releasing rehabilitated snakes to as near the site of capture as possible.

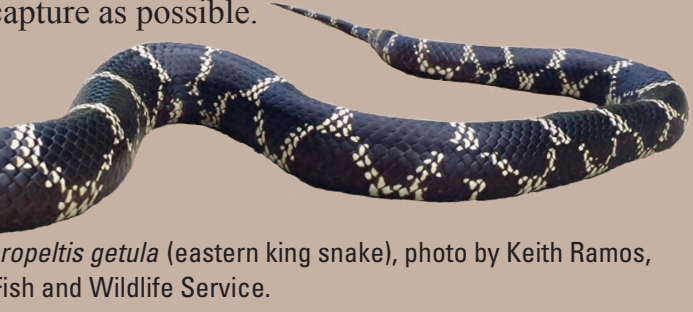

\section{Host Range of Ophidiomyces ophiodiicola (as of January 2018)}

In North America, O. ophiodiicola has been detected on the skin of captive and free-ranging snake species representing 12 genera within 2 families (Lorch and others, 2016), and including 2 species designated as threatened, Nerodia clarkia taeniata (Atlantic saltmarsh watersnakes) and Sistrurus catenatus (eastern massasauga rattlesnake), and one endangered species, Pituophis ruthveni (Louisiana pinesnake). Although presence of $O$. ophiodiicola has been documented in many specimens, not all have been sufficiently examined to characterize their susceptibility to infection by this fungus or the severity of disease that may result following infection. Ophidiomyces ophiodiicola, in conjunction with characteristic signs of SFD, have been detected on snakes in the following groups:

\section{Family: Colubridae}

- Coluber (racers)

- Farancia (mudsnakes)

- Lampropeltis (kingsnakes and milksnakes)

- Nerodia (watersnakes)

- Pantherophis (foxsnakes and ratsnakes)

- Pituophis (pinesnakes and bull snakes)

- Regina (crayfish snakes)

- Thamnophis (gartersnakes and ribbonsnakes)

- Virginia (earthsnakes)

\section{Family: Viperidae}

- Agkistrodon (copperheads and cottonmouths)

- Crotalus (rattlesnakes)

- Sistrurus (massasaugas and pigmy rattlesnakes)

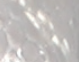

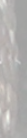 \\ (.}

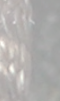




\section{U.S. Geological Survey Contributions to Understanding Snake Fungal Disease}

Scientists at the USGS are recognized leaders in advancing understanding of SFD. Specific contributions by USGS researchers include:

- Establishing that $O$. ophiodiicola is the cause of SFD;

- Developing laboratory methods to detect O. ophiodiicola;

- Studying the development and disease progression of SFD in captive snakes;

- Diagnosing SFD in snakes submitted by partner agencies to the National Wildlife Health Center;

- Coordinating field surveillance to monitor SFD infections in new populations or species;

- Establishing the past extent and geographic distribution of SFD and projecting its future course;

- Identifying other fungi, bacteria, or viruses that may independently cause skin infections in snakes or contribute to development of SFD; and

- Examining how SFD alters the behavior and survival of infected snakes to better understand the how the disease affects populations.

\section{References Cited}

Allender, M.C., Dreslik, Michael, Wylie, Sarah, Phillips, Christopher, Wylie, D.B., Maddox, Carol, Delaney, M.A., Kinsel, M.J., 2011, Chrysosporium sp. infection in Eastern Massasauga rattlesnakes: Emerging Infectious Diseases, v. 17, no. 12 , p. 2383-2384, accessed July 28, 2017, at https://doi. org/10.3201/eid1712.110240.

Allender, M.C., Raudabaugh, D.B., Gleason, F.H., Miller, A.N., 2015, The natural history, ecology, and epidemiology of Ophidiomyces ophiodiicola and its potential impact on free-ranging snake populations: Fungal Ecology, v. 17, p. 187-196, accessed July 28, 2017, at http://doi.org/10.1016/j. funeco.2015.05.003.

Bohuski, E., Lorch, J.M., Griffin, K.M., Blehert, D.S., 2015, TaqMan real-time polymerase chain reaction for detection of Ophidiomyces ophiodiicola, the fungus associated with snake fungal disease: BMC Veterinary Research, v. 11, no. 95, accessed July 28, 2017, at http://doi.org/10.1186/s12917-0150407-8.

Kabay, E., Caruso, N.M., and Lips, K., 2013, Timber rattlesnakes may reduce incidence of Lyme disease in the Northeastern United States: Ecological Society of America Annual Conference, $98^{\text {th }}$, Minneapolis, Minnesota, August 4-9, 2013.
Lorch, J.M., Knowles, Susan, Lankton, J.S., Michell, Kathy, Edwards, J.L., Kapfer, M.J., Staffen, R.A., Wild, E.R., Schmidt, K.Z., Ballmann, A.E., Blodgett, Doug, Farrell, T.M., Glorioso, B.M., Last, L.A., Price, S.J., Schuler, K.L., Smith, C.E., Wellehan, J.F.X., Blehert, D.S., 2016, Snake fungal disease: an emerging threat to wild snakes: Philosophical Transactions of the Royal Society B, v. 371, no. 1709, accessed July 28, 2017, at https://doi.org/10.1098/rstb.2015.0457.

Lorch, J.M., Lankton, J.S., Werner, Katrien, Falendysz, E.A., McCurley, K., Blehert, D.S., 2015, Experimental infection of snakes with Ophidiomyces ophiodiicola causes pathological changes that typify snake fungal disease: mBio, v. 6 , no. 6 , e01534-15, accessed July 28, 2017, at http://doi.org/10.1128/ mBio.01534-15.

McBride, M.P., Wojick, K.B., Georoff, T.A., Kimbro, Jason, Garner, M.M., Wang, Xiaoling, Childress, A.L., Wellehan, J.F.X., Jr., 2015, Ophidiomyces ophiodiicola dermatitis in eight free-ranging timber rattlesnakes (Crotalus horridus) from Massachusetts: Journal of Zoo and Wildlife Medicine, v. 46, no. 1, p. 86-94, accessed July 28, 2017, at http://doi. org/10.1638/2012-0248R2.1.

Mullin, S.J., Seigel, R.A., 2009, Snakes: Ecology and conservation: Ithaca, New York: Cornell University Press, 384 p.

Paré, J.A., Sigler, Lynne, Rypien, K.L., Gibas, C.C., 2003, Cutaneous mycobiota of captive squamate reptiles with notes on the scarcity of Chrysosporium anamorph of Nannizziopsis vriesii: Journal of Herpetological Medicine, and Surgery, v. 13, p. $10-15$.

Rajeev, S., Sutton, D.A., Wickes, B.L., Miller, D.L., Giri, D., Van Meter, M., Thompson, E.H., Rinaldi, M.G., Romanelli, A.M., Cano, J.F., Guarro, J., 2009, Isolation and characterization of a new fungal species, Chrysosporium ophidiicolo, from a mycotic granuloma of a black rat snake (Elaphe obsoleta obsoleta): Journal of Clinical Microbiology, v. 47, no. 4, p. 1264-1268, accessed July 28, 2017, at http://doi. org/10.1128/JCM.01751-08.

Sigler, Lynne, Hambleton, Sarah, Paré, J.A., 2013, Molecular characterization of reptile pathogens currently known as members of the Chrysosporium anamorph of Nannizziopsis vriesii complex and relationship with some humanassociated isolates: Journal of Clinical Microbiology, v. 51, no. 10 , p. 3338-3357, accessed July 28, 2017, at http://doi. org/10.1128/JCM.01465-13.

U.S. Fish and Wildlife Service, 2016, Eastern massasauga (Sistrurus catenatus) fact sheet, accessed July 28, 2017, at https://www.fws.gov/midwest/endangered/reptiles/eama/ eama-fct-sht.html.

\section{For additional information contact:}

Director, National Wildlife Health Center U.S. Geological Survey 6006 Schroeder Road Madison, WI 53711-6223 